\title{
SUB-NATIONAL CONSTRAINTS OF FISCAL POLICY-REVIEW OF THE EXPERIENCES OF SELECTED COUNTRIES
}

\author{
KATARZYNA WÓJTOWICZ
}

\begin{abstract}
This contribution deals with the problem of budgetary constraints imposed on local government units. The main aim is to provide descriptive characterization, classification, and evaluation of the advantages and disadvantages of subnational constraints of fiscal policy currently applied in selected countries. The experience of the European Union member states has been taken into account, as well as that of some OECD countries (Norway, Switzerland, USA, Australia and Canada) and countries cooperating with this organization (Brazil, Argentina). The article uses the method of critical analysis of the reports and statements issued by the European Commission and OECD, as well as that of legal acts and academic literature pertaining to the issues raised.
\end{abstract}

\section{Keywords}

Fiscal policy; financial safety; sub-central government units; constraints

JEL Classification: E62, G28, H74

\section{Introduction}

The problem of budgetary constraints imposed on local government units (LGUs), especially the limits of their access to loan funds, is one of the most poignant issues

Assistant professor at the Department of Public Finance at the Faculty of Economics of the Maria CurieSkłodowska University in Lublin. She specializes in the issues of local government finances, with a special focus on the fiscal stability of local government units (LGUs) and local public debt, as well as the local government tax system and municipal services financing. She is the author and co-author of many academic publications in this field (including books, chapters in monographs and scientific articles in Polish and English). She is a member of Organization Centre for the Research on the Public Finances and Tax Law in the Countries of Central and Eastern Europe. Contact email: kwojtowi@hektor.umcs.lublin.pl. 
for determining optimal fiscal relations between the central government and the local government sector. Local government units as one of the most important suppliers of public and merit goods, as well as the main public investor, are usually struggling with the insufficiency of their own budget revenues, which justifies their reaching for external funds. However, the specific functions of self-government public finances - especially when compared to central government public finances (Tiebout, 1956; Oates, 1998) - make it necessary for the use of debt instruments by local governments to be appropriately cautious and reasonable.

The publication of academic papers by the experts from the Fiscal Affairs Department of the International Monetary Fund (Ter-Minassian, 1997), which took place in the second half of the 1990s, as well as the reports prepared under the auspices of the Council of Europe, by the Steering Committee on Local and Regional Authorities (SCLRA 2000), were of fundamental importance for the development of economic research on institutional and legal subnational borrowing regulations. An important role was also played by comparative studies initiated by Dafflon (2002) on the limitations of access of local government units to capital markets. A vital trend is also constituted by the empirical research on the effectiveness of applying various types of a LGU budget constraints carried out in individual countries with the use of more or less complex econometric models. The results of these studies are not unambiguous and do not prove a clear relationship between budget constraints and the condition of local government finances (Braun 2006; Dufrénot et al.: 2010), while others indicate that this kind of a positive correlation indeed occurs (Poterba 1995; Martell 2008). An important part of the research is also constituted by crosssectional empirical studies, in which, based on the experience of properly selected groups of countries, an effort is made to delineate the most crucial determinants of the effectiveness of the budgetary constraints of LGUs, emphasising, among others, the importance of such elements as: the scope of horizontal fiscal imbalance (Rodden, Wibbels, 2002), the degree of local fiscal autonomy, bail-out expectations of LGUs, or transparency of budgetary process (Plekhanov, Singh 2007). The above publications were an incentive to address the issues of local government budget constraints also in Polish reference literature on the subject (Swianiewicz, 2004; Jastrzębska, 2006; Bitner, 2013; Wójtowicz, 2013).

Systems of subnational budget constraints have recently undergone quite significant transformations in many countries. At least two circumstances influenced this state of affairs. The first is a dynamic increase in public debt after the recent global financial crisis. For example, in the OECD countries, the ratio of the local government debt to GDP increased on average from ca. 53\% in 2007 to over $86 \%$ in 2015 (OECD 2017). The main debt generator is still the central government, but basing the local finance system of most countries on grants from the central 
government causes a "pushing" of government debt onto LGU budgets. The second circumstance observed in many countries is constituted by recentralisation tendencies, i.e. the striving to restore the dominant role of central government in the implementation of public tasks previously delegated to self-government. Both of the above trends have caused the necessity to once again pose a question as to the role of central governments in countries with a decentralized fiscal framework - and of the instruments, they could use to safeguard macroeconomic stability and the sustainability of public finances.

The aim of this study is to provide descriptive characterization, classification, and evaluation of the advantages and disadvantages of the currently applied ${ }^{2}$ budgetary constraints to which local government units operating in selected countries are subjected. Comparison of country experiences draws out core design issues concerning sub-national budgetary constraint mechanisms and demonstrates how the design of key elements of such regulations varies across countries. However, the paper does not prescribe how such mechanisms should be transferred to different institutional settings.

Above all, the experience of the European Union member states has been taken into account, as well as that of some OECD countries (Norway, Switzerland, USA, Australia and Canada) and countries cooperating with this organization (Brazil, Argentina). The article uses the method of critical analysis of the reports and statements issued by the European Commission and OECD, as well as that of legal acts and academic literature pertaining to the issues raised.

\section{Why Place Constraints on Sub-National Budgets?}

The concept of "budget constraints", as imposed on LGUs, should be understood as different types of institutional solutions, as well as legal regulations that define the scope, form or method of subnational borrowing. In particular, they limit the level of local public debt, the number of funds that can be allocated to servicing the debt, the purposes for which loan funds can be obtained, as well as the rules of issuing debt instruments abroad or issuing debt denominated in foreign currencies.

The following are usually indicated as the main arguments justifying the application of budgetary constraints at the level of local government units:

1. the insufficient effectiveness of economic instruments regulating the amount of the local government debt, 
2. the strong impact of the fiscal health of local government units on the fiscal sustainability, as well as on the macroeconomic stability of the state,

3. the existence of the so-called soft budget constraints and the phenomenon of the so-called moral hazard.

As regards the first premise, it should be noted that the increase in the demand for debt capital is usually accompanied by an increase in its cost, which limits the further increase of debtor's obligations. In the case of debt issued by local government units, the above-described market mechanism turns out to be unreliable; the reference literature on the subject indicates the following as the main reasons for this state of affairs (Dafflon, 2002):

- the assumption of a lack of bankruptcy capacity on the part of the LGUs as a consequence of their insolvency adopted by the capital providers;

- the limited information available to lenders;

- the high likelihood of a self-government unit failing to enter into bankruptcy activities to improve the financial situation until it is completely excluded from the market.

Another justification for imposing budget restrictions on LGUs is that the effects of local government debt burden the entire country, affecting both the sustainability of public finances and the general socio-economic situation alike. The degree of this impact is determined by both the scope and quality of fiscal decentralization, as well as by the level of economic development of a given country.

Finally, we ought to mention the existence of the so-called soft budgetary constraints, which should be understood as explicit or covert claims of local and regional authorities directed to state institutions in the application for financial assistance and support to cover the permanent budget deficits generated by the local government units in question (Kornai, 1986).

This attitude in relation to individual local government units is sometimes referred to as a moral hazard. The existence of soft budget constraints transfers the consequences of a potential insolvency of a local government unit onto the state budget, by replacing their own financial resources with state grants. In the long term, soft budget constraints may encourage local governments to be more aggressive in their debt policy. In extreme cases, the self-government which counts on bail-out may deliberately generate an excessive debt and take excessive risk in fiscal policy without taking care about such issues as the appropriate reduction of excessive expenses. 


\section{Classification of Local Budget Constraints}

In the subject literature, as well as in the budgetary practice of contemporary states, a certain classification has been established with reference to budgetary constraint systems imposed on local government units. Its basis is also constituted by the criterion of the budgeting process phase in which a specific limit is applied, as well as the criterion of the scope of fiscal autonomy of self-government authorities in defining their own budgetary goals and the legal status of these restrictions.

Depending on the phase of application of budget constraints, the following are distinguished: 1) ex-ante limits and 2) ex-post regulations (Martinez-Vasquez, Vulovic, 2016). The first of them is applied before the adoption of local government budgets, i.e. at the stage of their planning and preparation (Liu, Waibel, 2006).

Within this group of constraints, based on the criteria of fiscal autonomy of local authorities and on the legal status of these restrictions, it is possible to further distinguish the following models (Ter-Minassian, 1997; Eyraud, Sirera, 2015), (cf. Figure 1), i.e.:

- direct administrative control,

- fiscal rules,

- cooperation,

- market discipline.

The ex-post restrictions, in turn, consist of a set of predetermined mechanisms for the allocation of the default risk. They guarantee that in the case of a LGU insolvency, both the borrowers and the lenders would share the burden. Properly designed ex-post restrictions enforce the hard budget constraints (MartinezVasquez, Vulovic, 2016). 


\section{LIMITATIONS}
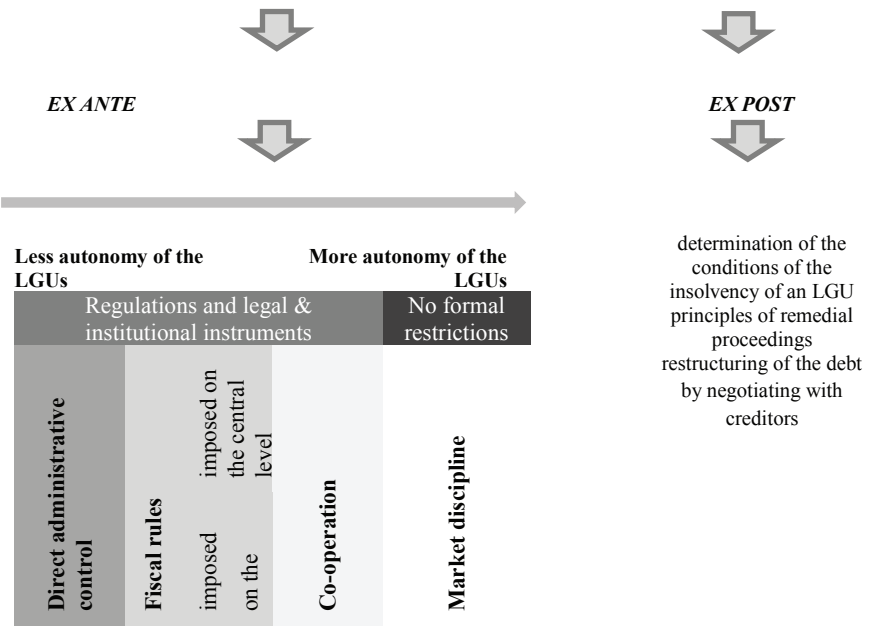

Source: Own elaboration based on Eyraud, Sirera, 2015.

Ex-post control mechanisms consist of three main elements, that is identification of the state of insolvency of a LGU, determination of a remedial principle that must be undertaken to restore fiscal sustainability and establishing the rules for restructuring the resulting debt by way of negotiating with the creditors (Figure 1). At the same time, two main practical approaches to this type of budget constraint can be distinguished, i.e. the use of judicial or administrative resolutions. In the first case, the insolvency of LGUs is announced over the course of court proceedings, while in the second case, the definition of the circumstances (prerequisites) that determine the implementation of the recovery program and the rules for its employment remain the domain of a higher level of public administration (i.e. most oftentimes that of the central government).

\section{Comparative Analysis of Ex Ante Subnational Budget Constraints}

In the ex-ante constraint group, the first category is constituted by legal and institutional solutions, among which the smallest range of a LGU fiscal autonomy is typical of the model of direct administrative control. In this model, the central government exerts a direct influence on the scope of the liabilities incurred by local government units by setting periodic debt limits as well as by establishing 
the specific debt conditions (e.g. the maturity or foreign debt participation). At the same time, it is possible to centralize all loan operations in the public finance sector and to grant local governments a certain limit of loans or credits taken for specific purposes. The main disadvantage of this approach, however, is the lack of any independence of local authorities in determining the level of debt, which seems to contradict the idea of fiscal decentralization and lead to the replacement of investment planning at the local level with central planning (Bitner, 2013). Secondly, this system favors the "moral hazard", forcing the central authorities to bail out LGUs in case of their insolvency - not only in a formal way but also in terms of the actual implementation of these rescue procedures.

The advantages of this approach include, first of all, the possibility for the government to maintain a strict impact on the macroeconomic stability and fiscal sustainability. This system also aids increasing the creditworthiness of local government units, especially towards foreign lenders, which may reduce the costs of incurring liabilities on financial markets (cf. Table 1).

In practice, this solution can be found in i.a. Denmark, Mexico, Great Britain, Canada, and India. It manifests itself in the existence of strict limits on the size of loans and borrowings incurred by local authorities, as well as in the specification of the purposes for which these debts may be allocated, such as, for example, investment expenditures. This requires obtaining the prior approval of the provincial authorities to incur liabilities by local self-government (Denmark, Canada, Great Britain), or to receive guarantees from the central government (India). Sometimes the scope of potential creditors, with whom local governments may get indebted, is limited only to domestic entities (Great Britain, Mexico).

The fiscal rules model requires the establishment of limits or restrictions that are governed by law, which affect the final shape of the fiscal policy. Most often they take the form of quantitative restrictions on the selected budgetary index (referring to such aspects as the level of budget deficit, the public debt, the size of the liabilities, the number of expenditures or the public revenues) which have a relatively stable nature (Symansky, Kopits, 1998). The main advantage of this approach is its transparency and the quite high efficiency from the point of view of ensuring long-term fiscal sustainability as well as intergenerational equity. The shortcomings of this system are associated with the existence of many factors that may weaken the effectiveness of the rules. In the case of local government units, these flaws include the tendency to raise loan funds using various forms of extrabudgetary economy, as well as tendencies to hide local government debt through the use of financial instruments not included in public financial liabilities. Constituting a further problem is also the volatility and arbitrariness of classification of budget 
expenditures as current liabilities or property expenditure (Wójtowicz, 2011; Bitner, 2013).

It is also worth paying attention to the pro-cyclical impact of some fiscal rules, which, in turn, is associated with the existence of trade-offs between their effectiveness in stabilizing public debt and in mitigating the negative effects of the cyclical market mechanism. The proper functioning of the fiscal rules system requires the creation of an appropriate mechanism to ensure compliance with such rules; such a system should encompass the following: the universality of sanctions, the speed, and reliability of their implementation and reliable reporting based on reliable and complete statistical data.

\section{Table 1 Characteristics of Advantages and Disadvantages of Different Models of Subnational Budget Constraints, as well as Description of Their Scope}

\begin{tabular}{|c|c|c|c|}
\hline Specification & Advantages & Disadvantages & $\begin{array}{c}\text { Implementing } \\
\text { states } \\
\text { (examples) }\end{array}$ \\
\hline $\begin{array}{l}\text { Direct } \\
\text { administrative } \\
\text { control }\end{array}$ & $\begin{array}{l}\text { maintaining the government's } \\
\text { direct influence on the overall } \\
\text { macroeconomic and fiscal policy of } \\
\text { the state } \\
\text { the possibility of reducing the costs } \\
\text { of the debts incurred (especially } \\
\text { in foreign markets) owing to the } \\
\text { presumption of state guarantees }\end{array}$ & $\begin{array}{l}\text { restricting the independence of local } \\
\text { self-government units with regards to } \\
\text { the level and directions of debt } \\
\text { "temptation of abuse" (moral hazard) } \\
\text { connected with the expectation of } \\
\text { financial support to be obtained } \\
\text { from the state budget in the event of } \\
\text { possible financial difficulties }\end{array}$ & $\begin{array}{l}\text { Denmark, } \\
\text { Mexico, } \\
\text { United } \\
\text { Kingdom, } \\
\text { Canada, India }\end{array}$ \\
\hline Fiscal rules & $\begin{array}{l}\text { transparency and simplicity } \\
\text { relatively high effectiveness in } \\
\text { achieving the assumed goals } \\
\text { adoption of these rules is a positive } \\
\text { market signal that may affect the } \\
\text { decline in debt servicing costs }\end{array}$ & $\begin{array}{l}\text { the possibility to circumvent rules } \\
\text { the pro-cyclical impact of some rules } \\
\text { the need to implement a system } \\
\text { that guarantees compliance with } \\
\text { the rules } \\
\text { the risk of mechanical budget cuts in } \\
\text { order to fulfill the rules (e.g. the risk } \\
\text { of lowering investment expenditures) } \\
\text { stiffening of budgetary policy }\end{array}$ & $\begin{array}{l}\text { many states } \\
\text { of the USA, } \\
\text { Norway, } \\
\text { Switzerland, } \\
\text { most of the } \\
\text { EU member } \\
\text { states }\end{array}$ \\
\hline Co-Operation & $\begin{array}{l}\text { promoting dialogue and information } \\
\text { exchange between participants in } \\
\text { the agreements } \\
\text { increasing the awareness of the self- } \\
\text { government authorities as regards } \\
\text { the macroeconomic and fiscal } \\
\text { impact of their budgetary resolutions }\end{array}$ & $\begin{array}{l}\text { requires close supervision by } \\
\text { the central authorities over the } \\
\text { implementation of agreements } \\
\text { requires a synchronized operation of } \\
\text { all parties to the agreement }\end{array}$ & $\begin{array}{l}\text { Austria, Spain, } \\
\text { Belgium, } \\
\text { Australia }\end{array}$ \\
\hline $\begin{array}{l}\text { Market } \\
\text { Discipline }\end{array}$ & $\begin{array}{l}\text { the flexible shaping of debt servicing } \\
\text { costs by the market } \\
\text { effectiveness under the condition } \\
\text { of significant development of } \\
\text { financial markets and a full access to } \\
\text { information }\end{array}$ & $\begin{array}{l}\text { the possibility to completely exclude } \\
\text { the debtor from the market } \\
\text { the inefficiency under the condition } \\
\text { of the so-called soft budget } \\
\text { constraints }\end{array}$ & $\begin{array}{l}\text { Canada, USA, } \\
\text { some Latin } \\
\text { American } \\
\text { countries }\end{array}$ \\
\hline
\end{tabular}

Source: Own elaboration based on 2013; Eyraud, Sirera, 2015; Martinez-Vazques, Vulovic, 2016. 

A LGU' budgetary restrictions in the form of fiscal rules are applied in many US states, in Norway, in Switzerland, as well as in most European Union countries (see Table 2); with the exception of the limits apply only to LGUs (on local and/or regional level), there are also rules relating to the general governments sector and, as a consequence, also to local government budgets.

\section{Table 2 Number of Fiscal Rules that Cover Local Government Sector in EU Countries in 2016, According to their Scope of Application}

\begin{tabular}{|l|c|c|c|c|}
\hline \multirow{2}{*}{ Rule type } & \multicolumn{4}{|c|}{ Rules covering the following with their scope: } \\
\cline { 2 - 5 } & $\begin{array}{c}\text { the general } \\
\text { governments } \\
\text { sector }\end{array}$ & $\begin{array}{c}\text { only the } \\
\text { local } \\
\text { governments }\end{array}$ & $\begin{array}{c}\text { only the I } \\
\text { regional } \\
\text { governments }\end{array}$ & $\begin{array}{c}\text { regional and local } \\
\text { governments }\end{array}$ \\
\hline Revenues & 1 & - & - & - \\
\hline Public debt & 13 & 10 & 2 & 0 \\
\hline Budget balance & 30 & 15 & 3 & 2 \\
\hline Expenditure & 13 & 2 & 1 & 0 \\
\hline In total & 57 & 27 & 6 & 2 \\
\hline
\end{tabular}

Source: Own elaboration based on the European Commission, 2017.

Among the rules implemented only at the local (and/or regional) level, the most important are the rules of budget balance and the rules of public debt (see Table 3).

\section{Table 3 Main Types of Fiscal Rules Applied Only at Local (and/or Regional) Level by Individual EU Member States in 2016}

\begin{tabular}{||l|c|c||}
\hline Rule Type & $\begin{array}{c}\text { no. of rules implemented } \\
\text { in 2015 }\end{array}$ & Country \\
\hline $\begin{array}{l}\text { Rules of the budget } \\
\text { balance }\end{array}$ & 20 & $\begin{array}{c}\text { Belgium, Bulgaria, Cyprus, Germany, Finland, } \\
\text { France, Ireland, Italy, Lithuania, Luxembourg, } \\
\text { the Netherlands, Poland, Portugal, Romania, } \\
\text { Sweden, and Slovakia }\end{array}$ \\
\hline Public debt rules & 12 & $\begin{array}{c}\text { Bulgaria, the Czech Republic, Estonia, Spain, } \\
\text { Latvia, Poland, Portugal, Romania, Slovakia }\end{array}$ \\
\hline Expenditure rules & 3 & Bulgaria, France, Italy \\
\hline Revenues rules & - & \\
\hline Total & 35 & \\
\hline
\end{tabular}

Source: Own elaboration based on European Commission, 2017.

They adopt at least a few varieties (Wójtowicz, 2013). One of them is the requirement to balance the total revenues of LGUs with their expenditure in a given fiscal period used i.a. in Belgium, Cyprus, Germany, Finland, and Sweden. Another fairly common variation of the budget balance rule in local government units is the so-called golden rule, according to which current expenditure should be equal to current revenues, whereas incurring public debt is only possible to cover capital 
expenditures (investments). This is the most popular constraint used in Germany (at regional level), in France (where, however, a current deficit is allowed at the stage of budget implementation, provided that it does not exceed 5\% of current revenue), in Italy, in Luxembourg, and under the name of the operational balance rule also in Portugal, Slovakia, Romania, Lithuania and in Poland. A different type of budget balance rule is the budget deficit limit in the form of a so-called budget anchor (Ireland), for instance. In the case of LGU budgets, however, the structural balance constraints - which are otherwise quite common at the level of the central government sector - are very rarely applied. Serving as an example here may be a rule introduced in 2014 in the Netherlands, which applies to all levels of subnational government (regions, provinces and local units), and in the event of exceeding the limits it establishes, appropriate corrective mechanisms have been provided.

The second most popular category of fiscal rules in local government units in EU countries is constituted by the rules of public debt. In 2016, 12 such rules were in force at the local and regional level and they were applied mainly in Central and Eastern Europe, as well as in Spain and Portugal. The most frequently encountered limitation is the debt limit expressed in relation to the level of budget revenues in the current or previous fiscal period. For example, in Estonia, this threshold amounts to $60 \%$ of total income, in Slovakia to $60 \%$ of the current revenues, while in Spain, after exceeding the limit of $75 \%$ of the current revenue, incurring further debt by local governments requires the consent of the central level authorities. Finally, there are rules referring to the ability to debt service capacity, which is most often determined in relation to the annual budget revenues $(15 \%$ in Bulgaria, $25 \%$ in Slovakia and $30 \%$ in Romania) or calculated on the basis of individual debt ratios calculated separately for each LGU (Poland). In the Czech Republic and in Latvia, the debt limit is determined by the central level authorities based on certain indices calculated for the whole local government sector. An interesting solution exists in Portugal, where the debt of a specific local government unit cannot exceed $150 \%$ of the average of the last three current budget revenues. In local government units of EU countries, there are no income rules and it is rare to use expenditure rules. The exception to this principle is the expenditure restriction applied at the regional level in Italy, which aims to stop the increase in public expenditure on health, as well as the new expenditure rules introduced in Bulgaria in 2014 and France in 2015 which determine the maximum allowable increase in local government expenditure.

Another model of LGU budget constraints - a co-operative one - consists in defining the limits of indebtedness in the local government sub-sector by way of negotiations between representatives of the central level authorities and lower levels of public authority (Bitner, 2013). This system assumes an active participation of local government units in determining the terms of such an agreement, taking 
into account the assumed macroeconomic and fiscal objectives. This solution is implemented in some countries of the European Union and in Australia. It is notable that this system is mainly used by countries with a federal system, in which the central government - most often than not - has no power to directly limit the debt of state-level authorities (Ter-Minassian, 1997). For example, in Austria in 1999, a consultation mechanism was introduced, the immediate objective of which was to limit the share of the fiscal deficit in GDP below the 3\% GDP criterion specified in the EU regulations (Martinez-Vazques, Vulovic, 2016). A similar agreement is also in force in Spain. On the other hand, in Belgium debt incurrence by the federal authorities is subject to the supervision of a special independent fiscal institution, which consists of representatives at all levels of public authority, as well as the central bank. Fiscal policy and decisions on incurring financial liabilities are coordinated in a similar fashion in some states in Australia. The cooperative approach combines the advantages of the previously implemented systems (Table 1). In particular, it is about promoting dialogue and information exchange between participants in the agreements, as well as about increasing their awareness of the macroeconomic consequences of certain budget decisions. On the other hand, this system requires that central authorities be able to effectively oversee and enforce the implementation of negotiated agreements.

The market discipline model assumes a lack of any formal limits on local government debt (Bitner, 2013). In this approach, the limits of LGU debt are shaped as a result of adjustment of the supply and demand side in the financial market. The market reacts to an increase in the borrower's debt by increasing the interest rate, which in turn affects the debt servicing costs. Above a certain threshold level of interest rates, lenders are no longer willing to provide debt capital due to the significant risk of the debtor's insolvency, and therefore it is even possible to foreclose them completely from the market. In this approach, the borrower's behavior is aimed at increasing creditworthiness and ensuring the long-term solvency of local government units in the absence of fundamental changes in the fiscal policy pursued. The reference literature, however, points to certain aspects conditioning the effectiveness of this system. First of all, financial markets should be free and open (in particular, in terms of an open access to local markets on the part of LGUs, which in most countries is subject to greater or smaller restrictions). Another issue is that of ensuring that the information on the factors determining the creditworthiness of borrowers is immediately available to lenders. In practice, this requirement poses a number of difficulties for methodical and accounting reasons related to the definition and classification of individual debt obligations, as well as due to the fairly common practice of hiding debt. Finally, it is worth noting that the market discipline system is ineffective in the context of the existence of soft budgetary constraints and in view of the moral hazard phenomenon. The market discipline system operates on 
the municipal capital market in the US, as well as in Canada, and in some Latin American countries, such as Argentina, Colombia, Brazil, and Peru (MartinezVazques, Vulovic, 2016). In the case of the USA and Canada, however, credit rating agencies play an important role in assessing the actual credit risk. It is worth noting that despite the significant degree of development of financial markets in both these countries, relying on the market discipline criterion did not protect them from the emergence of temporary debt crises in the local government sector in the mid-1990s. In turn, in Brazil and Argentina, some solutions were implemented in the 1980s to enhance the market discipline model, which, nonetheless, led to an explosion of the public debt in the local government sector and even to bankruptcies of some local government units (Martinez-Vazques, Vulovic, 2016).

\section{Conclusions}

A comparative analysis of subnational budgetary constraint mechanisms in selected countries points to the fact that their current shape was a more or less successful attempt to find the right balance between the benefits of accelerated development as a result of using debt financing and the risks arising from the use of specific debt instruments, as well as from the uncertainty about the size of future budget revenues and expenses.

At the same time, none of the analyzed four main models of LGU budget constraints turned out to be an optimal solution, and each of them, despite their advantages, also showed some drawbacks. For this reason, a selection of specific solutions is conditioned by the specificity of the functioning of the subnational governments in a given country, with special attention paid to the degree of fiscal autonomy of local authorities, the scope of public tasks assigned to them, and their constitutional positioning.

Among the analyzed models of fiscal constraints, the widest range of occurrences was typical of the fiscal rules model applied in the majority of EU countries, as well as in the USA, Norway, and Switzerland. Among the binding rules, the most poignant importance was held by the regulations which assumed balancing of local government budgets (whether comprehensive balancing or one conducted only in operational terms), which is described in the subject literature as an effective way to restore subnational fiscal sustainability.

However, what is noticeable in the countries surveyed is a gradual retreat from the model based only on market discipline and the lack of formal limits on indebtedness. Constituting the main reason for this state of affairs are the direct consequences of 
the last global financial crisis, which undermined the ability of the financial markets to effectively fulfill their regulatory function.

Another identifiable tendency is the inclination to combine solutions characteristic of various debt reduction models in the local government sector, in particular regarding the typical administrative and legal regulations with reference to the so-called good practices and standards governing mechanisms that promote cooperation and agreement between the central level authorities and local government units.

\section{References}

Bitner, M.: Reguły fiskalne ograniczające zaciąganie długu przez jednostki samorządu terytorialnego w wybranych krajach OECD - analiza prawno-porównawcza (Fiscal Rules restricting Borrowing by Territorial Self-government Units in Selected OECD Countries - Legal and Comparative Analysis), Samorząd Terytorialny (Territorial Government) no. 1-2 (2013).

Braun, M.: The Political Economy of Debt in Argentina, or Why History Repeats Itself. Paper presented at the World Bank Conference on Sovereign Debt and Development: Market Access Countries, Washington D.C., October 12-13, 2006.

Dafflon, B. (ed.): Local Public Finance In Europe. Balancing the Budget and Controlling Debt, Northampton: Edward Elgar Publishing Limited, 2002.

Dufrénot, G., Frouté, P., Schalck, C.: The French Regions' Borrowing Behaviours. How heterogeneous are they? Banque de France Document de Travail no. 289 (2010).

European Commission: Public finances in EMU - 2012, European Economy, Directorate-General for Economic and Financial Affairs no. 4 (2012).

European Commission: Fiscal Rules Database. New methodology. Directorate General Economic and Financial Affairs, 2017.

Eyraud, L., Sirera, R.G.: Constraints on subnational fiscal policy, in: Cottarelli, C., Guerguil, M. (eds.): Designing an European Fiscal Union. Lessons from the experience of fiscal federations, New York: Routledge Taylor\&Francis Group, IMF, 2015.

Jastrzębska, M.: Ograniczenia w zaciąganiu długu przez jednostki samorządu terytorialnego w Polsce na tle rozwiązań w państwach członkowskich Unii Europejskiej (Limitations of local government borrowing in Poland against the background of solutions of other the European Union Member States, Finanse Komunalne (Municipal Finances) no. 6 (2006).

Kornai, J.: The Soft Budget Constraint, Kyklos no. 1 (1986).

Liu, L., Waibel, M.: Subnational Borrowing Notes for Middle-Income Countries, The World Bank, 2006.

Martell, C.R.: Fiscal institutions of Brazilian municipal borrowing, Public Administration and Development, no. 1 (2008). 
Martinez-Vazques, J., Vulovic, V.: How well subnational borrowing regulations work?, Andrew Young School of Policy Studies Research Paper Series no. 7 (2016).

Oates, W.E.: The Economics of Fiscal Federalism and Local Finance, Cheltenham UK: Edward Elgar Publishing Limited, 1998.

OECD: Government at Glance, Public finance, and economics, 2017.

Plekhanov, A., Singh, R.: How should subnational government borrowing be regulated? Some crosscountry evidence, IMF Staff Papers no. 3 (2007).

Poterba, J.M.: Balanced budget rules and fiscal policy: Evidence from the states, National Tax Journal no. 48 (1995).

Rodden, J., Wibbels, E.: Beyond the fiction of federalism: Macroeconomic management in multitiered systems, World Politics no. 4 (2002).

SCLRA: Effects on the financial autonomy of local and regional authorities resulting from the limits set at European level on national public debt, Study Series: Local and Regional authorities in Europe no. 71 (2000).

Swianiewicz, P.: The Theory of Local Borrowing and the West-European Experience, in: Swianiewicz, P. (ed.): Local Government Borrowing: Risks and Rewards, Hungary: DFID and Open Society Institute, 2004.

Symansky, S., Kopits, G.: Fiscal policy rules, International Monetary Fund, IMF Occasional Paper no. 162 (1998).

Ter-Minassian, T. (ed.): Fiscal Federalism in Theory and Practice, Washington, D.C.: International Monetary Fund, 1997.

Tiebout, Ch.M.: A pure theory of local expenditures, Journal of Political Economy no. 5 (1956).

Wójtowicz, K.: Samorządowe reguły fiskalne jako sposób przywracania stabilności finansów publicznych - doświadczenia państw UE, Finanse i nieruchomości w rozwoju lokalnym i regionalnym (Sub-central Fiscal Rules as a Way to Restore Sub-national Fiscal Sustainability of the European Union states), Prace Naukowe Uniwersytetu Ekonomicznego we Wrocławiu (Scientific works of the University of Economics in Wroclaw) no. 280 (2013). 